\title{
Kelola
}

\section{PENGEMBANGAN MODEL MANAJEMEN PEMBELAJARAN BERBASIS TIK DI SEKOLAH DASAR}

\author{
Edna Maria \\ Magister Manajemen Pendidikan \\ FKIP-Universitas Kristen SatyaWacana \\ ednamaria4781@gmail.com \\ Eko Sediyono \\ Pasca Sarjana Sistem Informasi \\ FTI-Universitas Kristen Satya Wacana \\ eko@staff.uksw.edu
}

\begin{abstract}
The aim of this study is to develop model of ICT-based learning management. With this tools and model, school can be easily monitor and evaluate the educational process. This research done by Research and Development $(R \& D)$. The place of the research is at SD Kristen Satya Salatiga, and data collection used interviews, observation and documentation. The data were analyzed using descriptive analysis and triangulation technique to test data validation. The result of the research are: The first step is Decision Making of ICT-based Learning, The second step is Planning of ICT-based Learning, The Third step is Implementation of ICT-based Learning, The Fourth step is Evaluation of ICT-based Learning. The key success factor of this model is on the second step that is how the teachers make the lesson plans and cooperate with all the parties related to the ICT-based learning management.
\end{abstract}

Keywords : model, management, ICT-based learning 


\section{PENDAHULUAN}

Tantangan pendidikan era modern salah satunya adalah membekali generasi dengan keterampilan abad 21 (Anderson, 2010:20). Salah satu keterampilan yang harus dimiliki adalah keterampilan berkomunikasi menggunakan teknologi informasi dan kumunikasi (TIK). Sekolah sebagai penyelenggara pendidikan diharapkan dapat menjadi wadah pelatihan keterampilan tersebut bagi para siswanya. Sekolah Dasar jika dikembangkan menjadi sekolah modern yang memahami kebutuhan masa depan, diharapkan dapat menjadi wadah untuk membekali para siswa dengan keterampilan abad 21. Oleh karena itu, mutu pembelajaran perlu ditingkatkan.

Salah satu strategi peningkatan mutu pembelajaran yang perlu dioptimalkan oleh Sekolah Dasar modern adalah sekolah yang menyelenggarakan pembelajaran berbasis TIK. Pembelajaran berbasis TIK adalah pembelajaran yang mengintegrasikan TIK dalam pengelolaannya. Oleh karena itu, diperlukan suatu model untuk melaksanakan manajemen pembelajaran berbasis TIK di Sekolah Dasar.

Fakta di tempat penelitian menunjukkan bahwa sekolah berpotensi melaksanakan pembelajaran berbasis TIK namun belum memiliki model yang dapat menjadi acuan guru dan pihak-pihak terkait langsung maupun tidak langsung dengan manajemen pembelajaran berbasis TIK. Pengembangan manajemen akan dilakukan apabila ternyata di dalam pelaksanaan manajemen terdapat masalah.

Manajemen pada hakikatnya
merupakan proses pemecahan masalah, sehingga langkah-langkah manajemen tidak ubahnya sebagaimana langkah-langkah pemecahan masalah, yaitu: (1) Identifikasi masalah, (2) Diagnosis masalah, (3) Penetapan tujuan, (4) Pembuatan Keputusan,
Perencanaan, (6) Pengorganisasian,

Pengkoordinasian, (8) Pendelegasian, (9)

Penginisiasian, (10) Pengkomunikasian, (11)

Kerja dengan kelompok-kelompok,

Penilaian (Gorton, 1976).

Proses pembelajaran perlu direncanakan, dilaksanakan, dinilai, dan diawasi agar terlaksana secara efektif dan efisien.Hal ini mengandung arti bahwa perlu ada manajemen agar pembelajaran dapat terlaksana sesuai tujuan yang diharapkan. Manajemen yang dimaksud adalah manajemen pembelajaran. Manajemen Pembelajaran melibatkan 4 fungsi pokok yang menjadi langkah dalam kegiatan manajemen. Menurut Sa'ud dan Sumantri (2007:131) ada 4 peranan guru sebagai manajer dalam proses pengajaran sebagai berikut.

1. Merencanakan yaitu menyusun tujuan belajar mengajar (pengajaran). Perencanaan dilakukan dengan mengembangkan perencanaan tahunan, rencana semester, rencana bagian (pokok bahasan), rencana mingguan dan rencana harian (rencana pelajaran) (Syafaruddin dan Nasution, 2005:94). Perencanaan pembelajaran adalah seperangkat rencana dan pengaturan kegiatan pembelajaran, media pembelajaran, waktu, pengelolaan kelas, dan penilaian belajar. Manfaat perencanaan pembelajaran adalah untuk memudahkan pembuatan persiapan pembelajaran dan memudahkan pengembangan pembelajaran yang aktif, kreatif, efektif dan menyenangkan (Triwiyanto, 2015: 97-98).

2. Mengorganisasikan, yaitu menghubungkan atau menggabungkan seluruh sumber daya belajar mengajar dalam mencapai tujuan secara efektif dan efisien.

3. Memimpin, yaitu memotivasi para peserta didik untuk siap menerima materi pelajaran,

4. Mengawasi, yaitu apakah pekerjaan atau kegiatan belajar mengajar mencapai 
tujuan pengajaran, salah satunya melalui evaluasi pengajaran, sehingga diketahui hasil yang dicapai.

Fungsi pokok manajemen pembelajaran adalah perencanaan, pengorganisasian, kepemimpinan dan pengawasan (Sa'ud dan Sumantri, 2007:131). Berkaitan dengan integrasi TIK dalam pembelajaran, semua fungsi pokok manajemen pembelajaran tersebut dilaksanakan memanfaatkan keunggulan teknologi informasi dan komunikasi. Menurut Kusmana (2011:44), bukti otentik terjadinya pembelajaran berbasis TIK dapat dicermati dari Rencana Pelaksanaan Pembelajaran (RPP) yang disusun dan implementasinya yang dilaksanakan oleh setiap guru mata pelajaran di sekolah. Hal tersebut sesuai dengan prinsip pengembangan atau penyusunan RPP menurut Triwiyanto (2015:100) yaitu menerapkan teknologi informasi dan komunikasi serta mempertimbangkan penerapan TIK secara terintegrasi, sistematis, dan efektif sesuai dengan situasi dan kondisi. Menurut Kusmana (2011:44), RPP yang mengintegrasikan TIK dalam pembelajaran dapat disusun melalui 2 (dua) pendekatan, pendekatan idealis dan pendekatan pragmatis. Pendekatan idealis dimulai dengan menentukan topik kemudian tujuan pembelajaran yang ingin dicapai dan menentukan aktifitas pembelajaran dengan memanfaatkan TIK yang relevan untuk mencapai tujuan pembelajaran tersebut. Pendekatan pragmatis dapat diawali dengan mengidentifikasi TIK yang ada atau mungkin bisa dilakukan atau digunakan, kemudian memilih topik-topik apa yang bisa didukung oleh keberadaan TIK tersebut, dan diakhiri dengan merencanakan strategi pembelajaran yang relevan untuk mencapai kompetensi dasar dan indikator capaian hasil belajar dari topik pelajaran tersebut.

Pembelajaran yang efektif, tentu memerlukan manajemen yang efektif pula. Menurut Syafaruddin dan Nasution (2005:17) pembelajaran efektif ditangani oleh guru profesional melalui manajemen pembelajaran yang baik. Penelitian relevan terdahulu oleh Kyakulumbye, dkk. (2013:453) mengenai manajemen praktis integrasi TIK ke dalam kurikulum SD di Uganda menemukan bahwa gaya dan strategi manajemen yang terukur diperlukan agar integrasi TIK ke dalam kurikulum SD sukses dilakukan. Diperlukan manajemen kurikulum dan pembelajaran yang baik dalam mengintegrasikan TIK ke dalam kurikulum. Oleh karena itu, guru sebagai manajer utama dalam pembelajaran yang berbasis TIK memerlukan model manajemen yang memberikan gambaran secara keseluruhan tentang tahapan manajemen pembelajaran berbasis TIK.

Berdasarkan latar belakang masalah tersebut, rumusan masalah penelitian ini adalah bagaimana mengembangkan dan mengimplementasikan model manajemen pembelajaran berbasis TIK sehingga menghasilkan pembelajaran yang efektif.

\section{METODE PENELITIAN}

Penelitian ini merupakan penelitian dan pengembangan (Research and Development) yang dikembangkan oleh Sugiyono (2012). Langkah-langkah pengembangan yang dimaksud adalah sebagai berikut: (1) potensi dan masalah; (2) pengumpulan data; (3) desain produk; (4) validasi desain; (5) perbaikan desain; (6) Ujicoba produk; (7) Revisi Produk; (8) Ujicoba pemakaian; (9) Revisi Produk; dan (10) Produksi Masal. Langkah penelitian dan pengembangan ini dilakukan secara terbatas mulai dari langkah pertama sampai dengan langkah kelima.

Langkah awal dilakukan studi pendahuluan di lapangan mengenai potensi dan masalah berkaitan dengan man/SDM, method/model manajemen pembelajaran, material/sarana dan prasarana, machinel perangkat TIK dan money/dana yang dialokasikan untuk integrasi TIK dalam 
pembelajaran. Pada langkah kedua, pengumpulan data dilakukan melalui wawancara, observasi dan studi dokumen. Penelitian dilakukan di SD Kristen Satya Wacana Salatiga. Subyek penelitian adalah Kepala Sekolah, Koordinator Kurikulum, Koordinator Sarana dan Prasarana, Koordinator IT, dan guru. Uji validitas dan reliabilitas data yang telah didapat menggunakan uji kredibilitas (validitas internal). Teknik triangulasi sumber dan triangulasi teknik dilakukan sebagai pengujiannya. Teknik analisis data yang digunakan adalah analisis deskriptif kualitatif.

Pada langkah ketiga, Desain Produk dilakukan dengan merumuskan desain model pembelajaran berbasis TIK menggunakan pendekatan teori Gorton yang mendukung terwujudnya PAIKEM. Model yang digunakan adalah perpaduan antara model deskriptif dan model prediksi (Haryati, Sri, 2012). Model ini menerangkan langkah-langkah dalam mencapai tujuan dan pengaruh setiap langkah pada langkah lainnya secara lebih aktual berupa konsep yang belum diaplikasikan dalam uji coba namun telah melewati uji validasi. Pada langkah keempat, Validasi Desain dilakukan uji validasi produk yang memenuhi standar teori dan ilmiah oleh dua orang pakar, seorang pengambil kebijakan yaitu Kepala Sekolah SD Kristen Satya Wacana. Pada langkah kelima, perbaikan desain dilakukan berdasarkan hasil validasi dan saran dari validator sehingga diperoleh model manajemen pembelajaran berbasis TIK yang dapat dijadikan acuan dalam melaksanakan manajemen pembelajaran.

\section{HASIL DAN PEMBAHASAN}

Berdasarkan penelitian dan
pengembangan yang dilakukan, maka
dijabarkan langkahnya sebagai berikut:

\section{Potensi dan Masalah}

Berkaitan dengan Man/SDM, SD Kristen Satya Wacana memiliki potensi SDM yang memadai. Mayoritas guru sudah memanfaatkan TIK sehingga sangat berpotensi jika pengelolaan pembelajaran terintegrasi dengan TIK. Namun masih ada beberapa guru yang merasa nyaman dengan pembelajaran konvensional, sehingga tidak mengupayakan diri belajar menguasai TIK. Hal ini sesuai dengan wawancara dengan Koordinator Kurikulum ketika ditanya mengenai kesulitan guru-guru dalam merencanakan pembelajaran yang memanfaatkan TIK.

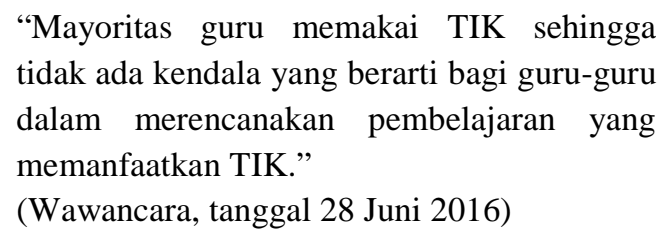

Hal itu diperjelas oleh Koordinator IT dan Kepala sekolah saat ditanya mengenai potensi pembelajaran yang memanfaatkan TIK:

"Potensi pembelajaran yang memanfaatkan
TIK besar karena guru-guru di sekolah ini
mau belajar hanya 1 atau 2 guru yang benar-
benar tidak mau belajar menggunakan TIK." (Wawancara, tanggal 01 Juli 2016)

"Sejauh ini integrasi TIK dalam pembelajaran masih tergantung pada guru, belum semua melaksanakan karena ada beberapa guru yang penguasaan TIKnya belum optimal. Namun guru yang sudah menguasai pasti selalu menggunakan TIK."

(Wawancara, Kepala Sekolah, 30 Juni 2016)

Data dari hasil wawancara dengan guru, Koordinator IT menunjukkan bahwa guru masih mengalami kesulitan dalam menguasai TIK. Hal itu juga dikuatkan oleh data dokumentasi RKS (Rencana Kerja Sekolah) tahun pelajaran 2015/2016 mengenai pengadaan pelatihan TIK di SD Kristen Satya Wacana yang belum terlaksana padahal target yang diharapkan dilaksanakan dua kali dalam satu tahun pelajaran. Hal ini tentu saja akan mengurangi kesempatan pembekalan TIK bagi guru terutama yang belum menguasai TIK. 
Berkaitan dengan method/model manajemen pembelajaran, manajemen pembelajaran yang dilakukan di SD Kristen Satya Wacana menganut kurikulum baru yaitu kurikulum 2013. Pelaksanaan pembelajaran yang memanfaatkan TIK oleh guru sudah dilakukan namun dalam hal perencanaan pembelajaran guru-guru merasa kesulitan dalam hal penyiapan administrasi kelas seperti pembuatan silabus dan RPP. Jika dikaitkan dengan efektivitas manajemen pembelajaran yang dilaksanakan di SD Kristen Satya Wacana, dapat dinilai belum maksimal. Berdasarkan fakta di lapangan bahwa dari semua guru SD Kristen Satya Wacana yang diwawancara, sebagian besar belum membuat RPP sebagai pedoman bagi perencanaan pembelajaran. Padahal menurut Bafadal, (2009:41-42) perencanaan yang baik disertai dengan rincian yang teliti itu harus dilakukan dengan sebaik-baiknya.

Berkaitan dengan material/sarana dan prasarana, SD Kristen Satya Wacana dalam hal sarana prasarana cukup memperhatikan pemenuhan kebutuhan bagi berlangsungnya pembelajaran. Hal ini dikemukakan dalam wawancara dengan guru-guru dan Koordinator Sarpras bahwa sekolah sudah mengupayakan pengadaan sarana prasarana semaksimal mungkin sesuai anggaran. Masalah yang dikeluhkan adalah pemeliharaan sarana prasarana yang sudah tersedia. Data yang peneliti peroleh mengenai sarana dan prasarana di SD Kristen Satya Wacana dikuatkan oleh wawancara, observasi dan dokumentasi.

Berkaitan dengan machine/perangkat TIK, SD Kristen Satya Wacana sudah berusaha mengupayakan pengadaan perangkat TIK.Masalah yang selama ini menjadi kendala berkaitan dengan perangkat TIK yang dimiliki sekolah adalah dalam hal pemeliharaan. Seperti yang terungkap dari wawancara dengan Koordinator IT dan guru-guru bahwa laboratorium komputer dalam keadaan rusak, hanya beberapa komputer saja yang dapat dipakai, yang lain meski sudah diperbaiki tetap saja rusak lagi, sehingga ini menghambat pembelajaran yang menggunakan laboratorium komputer. Data yang terangkum telah diverifikasi oleh data terbaru dari Koordinator Sarpras.

Berkaitan dengan money/dana yang dialokasikan untuk integrasi TIK dalam pembelajaran, secara lebih spesifik pengalokasian dana untuk integrasi TIK dalam pembelajaran sudah ada namun terbatas dan masih menjadi kendala utama. Hal ini dikemukakan oleh Kepala Sekolah dalam wawancara mengenai pengelolaan infrastruktur TIK di sekolah dan kendala integrasi TIK dalam pembelajaran seperti dikutip sebagai berikut:

“...Kebutuhan akan pendanaan dengan
batasan lima ratus ribu rupiah, di atas nilai
tersebut pengadaan infrastruktur seijin
kepalasekolah namun di bawah nilai tersebut
langsung dengan Koordinator Sarpras.
...Kendala utama ada pada biaya, misalnya
mengenai pengadaan laboratorium komputer,
pemeliharaan LCD, setting ruang khusus TIK
belum ada, dana untuk kebutuhan fotocopy
lembar aktifitas siswa cukup besar kurang
lebih dua juta per bulan."
(Wawancara, Kepala Sekolah, 30 Juni 2016)

Data wawancara mengenai dana dengan kepala sekolah dikuatkan dengan data dari Koordinator Sarpras dan Kepala Tata Usaha.

\section{Desain Produk}

Pengembangan model manajemen pembelajaran berbasis TIK dilakukan dengan merumuskan desain model manajemen pembelajaran dengan pendekatan teori oleh Gorton. Langkah 1-4 merupakan model pengambilan keputusan (Usman, 2006:322325). Langkah manajemen dengan pendekatan teori Gorton dapat disederhanakan menjadi empat tahap berdasarkan kebutuhan akan manajemen pembelajaran, yakni Tahap Pengambilan Keputusan Pembelajaran, Tahap 
Perencanaan Pembelajaran, Tahap masalah, maka dibuat desain model Pelaksanaan Pembelajaran, dan Tahap manajemen pembelajaran berbasis TIK yang Evaluasi Pembelajaran. Tahap - tahap tersebut mendukung terwujudnya PAIKEM. Langkah dapat dikembangkan menjadi model manajemen tersebut terlihat seperti gambar di manajemen pembelajaran berbasis bawah ini:

TIK.Berdasarkan hasil analisis potensi dan

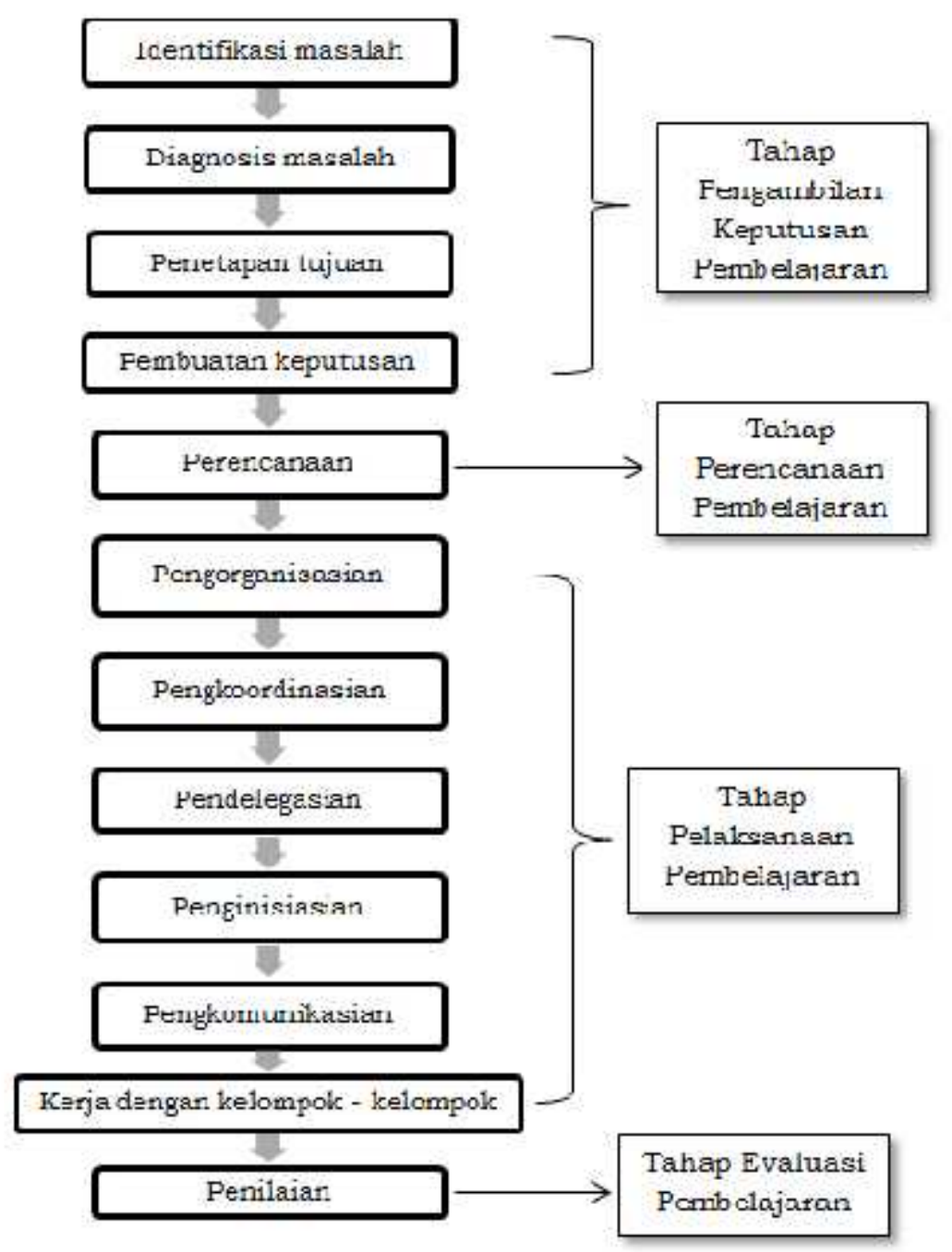

Gambar 1 Langkah Manajemen Pembelajaran Pendekatan Teori Gorton

Model manajemen pembelajaran berbasis TIK ini melibatkan pihak-pihak yang terkait baik langsung maupun tidak langsung dalam pembelajaran berbasis TIK diantaranya adalah: Kepala Sekolah, Koordinator bidang
Kurikulum, Koordinator bidang IT, Koordinator bidang Sarana dan Prasarana, serta guru. Masing-masing pihak memiliki peran dalam langkah manajemen seperti pada gambar di bawah ini: 


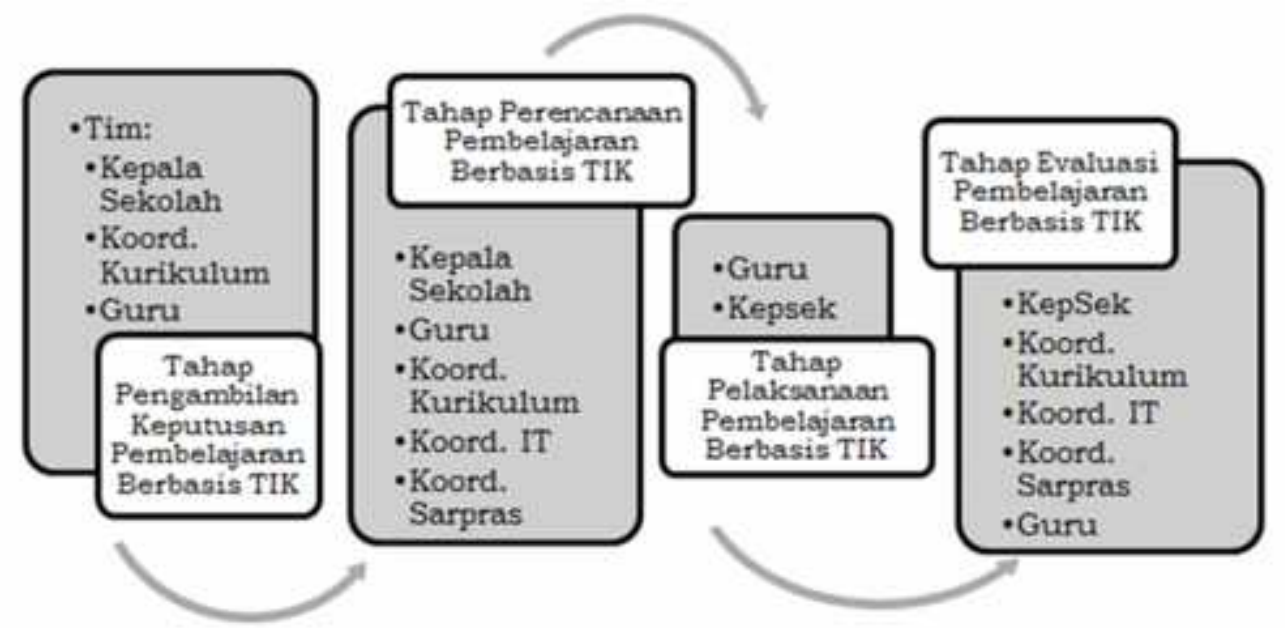

Gambar 2 Tahapan dan Pelaksana Manajemen Pembelajaran Berbasis TIK

Tahap Pengambilan Keputusan Pembelajaran Berbasis TIK melibatkan tim yang terdiri dari: Kepala Sekolah, Koordinator bidang Kurikulum dan Guru. Pada Tahap Perencanaan Pembelajaran Berbasis TIK melibatkan Kepala Sekolah, Guru, Koordinator Kurikulum, Koordinator IT, serta Koordinator Sarana dan Prasarana. Pada Tahap Pelaksanaan Pembelajaran Berbasis TIK melibatkan Guru, Koordinator IT dan Koordinator Sarana dan Prasarana. Pada Tahap Evaluasi Pembelajaran Berbasis TIK melibatkan Kepala Sekolah, Koordinator Kurikulum, Kurikulum IT, Koordinator Sarana dan Prasarana serta Guru.

Pada tahap pengambilan keputusan pembelajaran berbasis TIK, Kepala Sekolah berhak mengambil segala keputusan terhadap adanya pembelajaran. Kepala Sekolah terlebih dahulu mengidentifikasi masalah pembelajaran berbasis TIK, apakah berkaitan dengan kebijakan ataukah berkaitan dengan pembiayaan. Setelah didiagnosis apakah ada kecukupan anggaran atau dasar kebijakan untuk program pembelajaran berbasis TIK yang diajukan oleh Koordinator Kurikulum maka perlu ditetapkan tujuan program pembelajaran berbasis TIK sehingga berujung kepada pembuatan keputusan berdasar kebijakan atau kecukupan anggaran program pembelajaran tersebut.
Pada tahap pengambilan keputusan, guru juga mempunyai wewenang dalam halhal yang berkaitan langsung dengan materi pembelajaran yang akan diberikan pada siswa di kelas. Guru sebelum merencanakan pembelajaran berbasis TIK perlu mengidentifikasi dan mendiagnosis masalah yang berkaitan dengan kebutuhan integrasi TIK dalam pembelajaran seperti materi pembelajaran dalam bentuk konten digital, kebutuhan siswa, ketersediaan infrastruktur untuk kemudian menetapkan tujuan pembelajaran dan membuat keputusan pembelajaran berbasis TIK sesuai dengan keputusan Kepala Sekolah.

Pada tahap Perencanaan Pembelajaran Berbasis TIK, Kepala Sekolah ikut terlibat dalam perencanaan pembelajaran berbasis TIK selaras dengan perencanaan pembelajaran oleh guru dan sesuai dengan pengembangan kurikulum serta penjadwalan guru oleh Koordinator Kurikulum. Perencanaan pembelajaran berbasis TIK yang dibuat oleh Guru bekerjasama dengan Koordinator IT dan Koordinator Sarpras dalam hal kesiapan infrastruktur, konten digital dan penjadwalan penggunaan sarpras yang dibutuhkan pada saat pelaksanaan pembelajaran. Guru dapat menggunakan salah satu dari dua pendekatan perencanaan pembelajaran yang berbasis TIK yaitu pendekatan idealis atau pendekatan pragmatis. Guru juga harus merencanakan 
strategi pembelajaran yang relevan (Kusmana, 2011:44).

Tahap Pelaksanaan Pembelajaran Berbasis TIK melibatkan Guru sebagai manajer utama dalam pembelajaran. Guru melakukan pengorganisasian sumber daya belajar yang berbasis TIK, kemudian mengkoordinasikan tugas-tugas pembelajaran dengan siswa sesuai dengan RPP yang telah dibuat. Guru selanjutnya mendelegasikan tugas-tugas tersebut pada siswa sesuai dengan kemampuan siswa menggunakan TIK.

Pada pelaksanaan pembelajaran guru juga melakukan penginisiasian yaitu pengerahan atau kepemimpinan dimana guru memotivasi peserta didik untuk siap berperan aktif dalam pembelajaran. Guru kemudian mengkomunikasikan materi yang berupa konten digital kepada siswa menggunakan perangkat TIK yang telah direncanakan. Pembelajaran berbasis TIK dapat dilaksanakan dengan teknik berkelompok. Hal ini akan memudahkan siswa dalam bekerjasama dan bertukar informasi serta mengatasi masalah pemerataan kemampuan siswa dalam menggunakan TIK dalam pembelajaran. Pada tahap ini, Kepala Sekolah juga melakukan monitoring dan evaluasi melalui kegiatan supervisi terhadap pelaksanaan pembelajaran yang dilakukan oleh guru (Triwiyanto, 2015:66).

Tahap terakhir dalam manajemen pembelajaran berbasis TIK adalah Evaluasi Pembelajaran berbasis TIK. Pada tahap ini melibatkan Koordinator Kurikulum dalam hal mempersiapkan penjadwalan kegiatan evaluasi seperti Tes yang bersifat formatif seperti ulangan harian dan sumatif yaitu Tes Tengah Semester, Tes Akhir Semester. Koordinator Kurikulum bekerjasama dengan guru dalam pengadaan soal tes yang berbasis TIK dibantu oleh Koordinator IT dan Koordinator Sarpras. Kepala Sekolah pada tahap ini juga melaksanakan kegiatan supervisi pembelajaran untuk memantau evaluasi pembelajaran.
Hasil akhir yang diharapkan dari setiap tahapan adalah sebagai berikut:

Tahap Pengambilan Keputusan Pembelajaran Berbasis TIK menghasilkan Program Pembelajaran yang tertuang dalam RKS (Rencana Kerja Sekolah) serta Program dan Anggaran tiap bidang berkaitan dengan anggaran kebutuhan program pembelajaran berbasis TIK. Program pembelajaran yang direncanakan dapat berupa program e-education misalnya e-learning, e-library. Setelah dibuat keputusan bersama untuk tiap bidang yang terkait langsung dengan pembelajaran di kelas (Bidang Kurikulum, Bidang Sarana Prasarana, Bidang IT) dan disahkan oleh Kepala Sekolah, maka dapat dilanjutkan ke tahap selanjutnya.

Tahap Perencanaan Pembelajaran Berbasis TIK menghasilkan Prota, Promes, Silabus, Rencana Mingguan serta Rencana Harian atau RPP dengan pendekatan integrasi TIK. RPP yang terintegrasi TIK ini disusun dan dikembangkan bersama melibatkan Kepala Sekolah berkaitan dengan supervisi pembelajaran; Koordinator Kurikulum; berkaitan dengan program dan anggaran yang telah dibuat; Koordinator Sarpras berkaitan dengan ketersediaan dan penjadwalan penggunaan sarpras; Koordinator IT dibantu dengan timnya berkaitan dengan materi pembelajaran berupa konten digital atau aktifitas pembelajaran yang memanfaatkan TIK yang harus dipersiapkan.

Tahap Pelaksanaan Pembelajaran Berbasis TIK menghasilkan PAIKEM (Pembelajaran Aktif, Inovatif, Kreatif, Efektif, Menyenangkan). Siswa melalui TIK dimungkinkan untuk ikut aktif dalam pembelajaran, menghasilkan karya yang bersifat inovatif, kreatif sehingga siswa mencapai tujuan pembelajaran sebagaimana yang diharapkan. 
Keterlibatan siswa membuat siswa belajar asyik dengan percaya diri dan tertantang untuk melakukan hal serupa atau bahkan hal yang lebih berat lagi.

- Tahap Evaluasi Pembelajaran Berbasis TIK menghasilkan hasil penilaian yang sahih, objektif, adil, terpadu, terbuka, menyeluruh dan berkesinambungan, sistematis, beracuan kriteria, serta accountable (Triwiyanto, 2015:190). Hal tersebut dimungkinkan dengan melaksanakan tes berbasis komputer. Pengelolaan sistem penilaian ini akan menjadi efisien dalam hal penghematan biaya pengadaan kertas dan waktu untuk proses koreksi, karena tergantikan dengan sistem komputer yang dibuat dalam bentuk program komputer. Hasil penilaian dilaporkan kepada orangtua siswa dalam bentuk rapor baik laporan pendidikan di tengah semester maupun di akhir semester dalam bentuk digital (berbasis web atau berbasis mobile) dan atau kertas.

Berkaitan dengan kegiatan supervisi pembelajaran berbasis TIK yang merupakan bagian dari pengawasan atau monitoring dan evaluasi, Kepala Sekolah akan lebih mudah melaksanakannya jika semua tahap masuk dalam sistem berbasis internet yang dapat diakses dimana saja dan kapan saja. Model manajemen pembelajaran berbasis TIK seperti gambar di bawah ini:

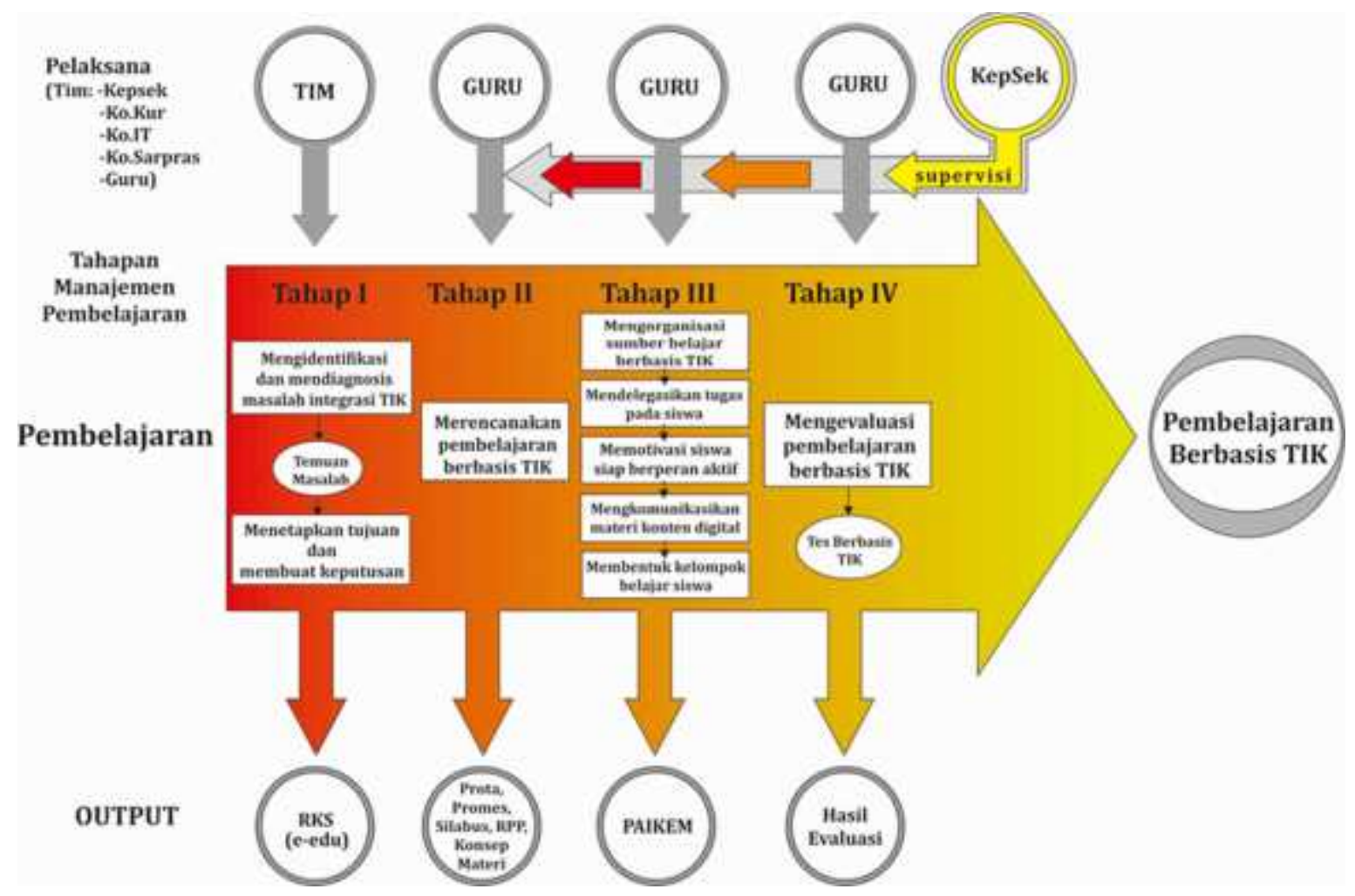

Gambar 3 Model Manajemen Pembelajaran Berbasis TIK

\section{ValidasiProduk}

Model Pembelajaran Berbasis TIK divalidasi oleh 3 Validator yaitu: (1) Dr. Bambang Suteng Sulasmono, M. Si. (2) Dr. Dra. Ade Iriani, M. M. (3) Pujiono, S. Pd. Beberapa saran dari validator tersebut antara lain: Validator 1: Terdapat banyak struktur kalimat yang perlu diperbaiki. Beberapa bagian perlu dielaborasi lebih lanjut agar semakin jelas, Validator 2: Perbaikan tata bahasa dalam bahasa Indonesia yang baik, Validator 3: Perlu ditambahkan tujuan yang sasarannya untuk siswa. Perlu penataan sub 
judul agar tidak terpisah dari uraiannya agar memudahkan dalam membaca.

\section{PerbaikanProduk}

Berdasarkan hasil validasi dan saran dari validator, selanjutnya dilakukan perbaikan sehingga diperoleh model manajemen pembelajaran berbasis TIK yang dapat dijadikan acuan untuk pelaksanaan manajemen pembelajaran. Perbaikan yang dilakukan antara lain: memperbaiki struktur kalimat, mengelaborasi pada bagian konsep pembelajaran berbasis TIK dan menambahkan halaman rujukan pada bagian yang memerlukan rujukan konsep; memperbaiki tata bahasa yang belum menggunakan bahasa Indonesia yang baik sehingga jelas subyek, predikat, obyek dan keterangannya; menambahkan tujuan yang berkaitan dengan siswa dan menata kembali sub judul agar tidak terpisah dari uraiannya sehingga mudah dibaca.

\section{Pembahasan}

Model ini disesuaikan dengan situasi dan kondisi tempat penelitian agar dapat diimplementasikan dengan mudah. Keberhasilan implementasi model kembali kepada pelaksanaan secara menyeluruh, bertahap dan sesuai dengan kerjasama semua pihak yang terkait dengan pembelajaran.

Kunci keberhasilan model manajemen pembelajaran berbasis TIK terletak pada tahap perencanaan pembelajaran berbasis TIK yang dikerjakan oleh guru melibatkan pihak-pihak yang terkait langsung dengan pembelajaran berbasis TIK. Sesuai fungsi dari perencanaan pembelajaran adalah sebagai panduan atau pedoman dalam penyusunan program pembelajaran, penyiapan proses pembelajaran, penyiapan bahan/media/sumber belajar, dan penyiapan perangkat penilaian sehingga memudahkan pembuatan persiapan pembelajaran dan pengembangan 68 pembelajaran PAIKEM (Triwiyanto, 2015:9798).

Melalui perencanaan pembelajaran, persiapan integrasi TIK dalam RPP disusun dengan pertimbangan sedemikian rupa menyesuaikan situasi dan kondisi sekolah. Kesulitan yang dihadapi guru dalam pengembangan RPP dapat diatasi dengan melakukan kerjasama dengan guru lain yang memegang tingkat kelas yang sama dengan fasilitasi dan supervisi oleh kepala sekolah atau guru senior yang ditunjuk.

Penelitian terdahulu yang berkaitan dengan pengembangan manajemen pembelajaran lebih memfokuskan pada integrasi TIK dalam pembelajaran, penelitian lain yang dilakukan mengembangkan model sistematik integrasi TIK (Wang dan Woo, 2007:148-156) dan mengenai model umum untuk membimbing integrasi TIK dalam pengajaran dan pembelajaran (Wang, 2008:411-419). Kedua penelitian ini merupakan bagian dari manajemen pembelajaran namun bukan model manajemen pembelajaran itu sendiri.

Penelitian lain lebih menekankan pada manajemen integrasi TIK ke dalam kurikulum sekolah dasar (Kyakulumbye dan Katono, 2013). Fungsi manajemen yang digunakan hanya tiga yaitu perencanaan, pengorganisasian dan pengkoordinasian. Kesamaan kunci model pada penelitian ini adalah pada fungsi perencanaan. Perencanaan menjadi salah satu aspek kunci dalam manajemen kurikulum. Fungsi manajemen yang dikaji pada penelitian tersebut melibatkan manajer sekolah dan guru. Hampir sama namun belum menjelaskan secara lengkap sampai kepada fungsi manajemen yang terakhir namun penting yaitu evaluasi. Menurut Triwiyanto (2015:183) fungsi evaluasi dilakukan untuk menilai efisiensi, efektivitas, manfaat, dampak dan keberlanjutan suatu program atau kegiatan dalam hal ini program pembelajaran. Dari 
fungsi evaluasi akan dapat diukur ketercapaian program yaitu sejauh mana kegiatan pembelajaran dapat dilaksanakan.

Ada tiga komponen kunci yang mempengaruhi efektivitas integrasi TIK dalam pengajaran dan pembelajaran yaitu pedagogi, interaksi sosial dan teknologi. Namun selain ketiga komponen tersebut, kemampuan manajemen juga merupakan keterampilan yang penting diperlukan dalam rangka melaksanakan pembelajaran berbasis TIK (Wang, 2008:417). Model manajemen pembelajaran berbasis TIK ini berfokus pada fungsi manajemen yang diperlukan dalam melaksanakan pembelajaran berbasis TIK dari awal sampai akhir. Faktor kunci yang berkaitan dengan implementasi TIK selain sikap dan etos yaitu koordinasi dan manajemen (Tearle, 2004). Secara teori, model ini sudah mendapat landasan yang kuat bahwa diperlukan gambaran manajemen yang jelas dan terukur untuk mencapai tujuan pembelajaran berbasis TIK.

Model manajemen pembelajaran berbasis TIK ini cukup lengkap dikembangkan dengan tujuan agar efektivitas manajemen diperoleh secara maksimal. Jika ditinjau dari manfaat teoritis, model ini menyajikan lengkap dengan tahap pengambilan keputusan yang dilaksanakan sebelum tahap perencanaan. Inilah yang menjadi kebaruan dari model manajemen pembelajaran ini. Masalah yang ditemukan berdasarkan evaluasi pembelajaran yang lalu dapat menjadi dasar pengambilan keputusan bagi perencanaan pembelajaran yang akan datang. Hasil penelitian terdahulu menyatakan bahwa sekolah berbasis TIK perlu rencana kebijakan TIK yang jelas agar koordinator yang ditunjuk sebagai pemimpin memiliki arahan kerja yang jelas pula (Vanderlinde, dkk, 2012). Hasil evaluasi proses pembelajaran yang sebelumnya perlu dipertimbangkan dalam rangka membuat keputusan. Temuan masalah yang didapat dari tahap ini akan menjadi dasar untuk menentukan kebutuhan pembelajaran yang akan datang.

Kemudahan dalam monitoring dan evaluasi proses pembelajaran yang dilakukan baik oleh guru maupun kepala sekolah akan terwujud. Hal ini dimungkinkan dengan adanya teknologi komputer yang menghilangkan batasan waktu dan jarak dalam melaksanakan proses monitoring dan evaluasi pembelajaran. Pimpinan sekolah perlu mengelola pemanfaatan TIK dengan beberapa strategi pengelolaan TIK agar dapat bermanfaat bagi peningkatan pembelajaran (Adu, Olatundun, 2013:11). Kepala sekolah dapat mengembangkan teknik supervisi memanfaatkan teknologi komputer sebagai alat untuk melaksanakan proses monitoring dan evaluasi pembelajaran. Supervisi dengan teknik kunjungan kelas sudah biasa dilakukan bahkan telah diteliti (Danurwati dan Slameto, 2015:99-109). Guru mendapatkan bantuan berupa arahan dan dorongan secara langsung setelah supervisor melakukan kunjungan kelas. Ada beberapa kelemahan jika supervisor hadir dalam kelas, guru ataupun murid merasa canggung dengan kehadiran orang lain yang tidak biasa di dalam kelas selama proses pembelajaran. Jika tujuan kunjungan kelas adalah untuk memperoleh data mengenai proses pembelajaran yang dilaksanakan, maka dengan memanfaatkan model manajemen pembelajaran berbasis TIK, supervisor dapat memperoleh data proses pembelajaran dengan bantuan teknologi jaringan dan dengan bantuan kamera. Hal tersebut tidak akan mengganggu berlangsungnya proses pembelajaran namun justru mempermudah. Supervisor juga dapat melihat data perencanaan pembelajaran yang dibuat oleh guru dengan mengakses ke sebuah web database dengan password khusus serta kemudian mengevaluasi apakah sudah sesuai dengan pelaksanaan pembelajaran, sehingga dapat diperoleh solusi yang tepat bagi kesulitan yang guru hadapi. 
SIMPULAN DAN SARAN

\section{Simpulan}

Melalui kegiatan penelitian dan pengembangan ini telah didapatkan gambaran mengenai manajemen pembelajaran yang saat ini dibuat dan dilaksanakan di SD Kristen Satya Wacana Salatiga bahwa selain guru ada keterlibatan kepala sekolah, koordinator kurikulum, koordinator IT serta koordinator sarpras. SD Kristen Satya Wacana mempunyai potensi untuk melaksanakan pembelajaran berbasis TIK namun masih ada masalah dalam perencanaan manajemen pembelajaran yang berbasis TIK.Manajemen pembelajaran yang sudah dilaksanakan di SD Kristen Satya Wacana belum efektif karena sebagian besar guru belum menyusun dan mengembangkan RPP yang menjadi acuan rinci bagi guru dalam melaksanakan pembelajaran terutama pembelajaran yang berbasis TIK.

Model manajemen pembelajaran berbasis TIK yang dikembangkan terdiri dari 4 tahap yakni: (1) Tahap Pengambilan Keputusan Pembelajaran Berbasis TIK; (2) Tahap Perencanaan Pembelajaran Berbasis TIK; (3) Tahap Pelaksanaan Pembelajaran Berbasis TIK; dan (4) Tahap Evaluasi Pembelajaran Berbasis TIK. Ada hasil akhir yang diharapkan dari masing-masing tahapan yakni: (1) RKS yang berisi program pembelajaran berbasis TIK; (2) RPP yang terintegrasi dengan TIK; (3) PAIKEM; (4) Hasil Evaluasi yang sahih, objektif, adil, terpadu, terbuka, menyeluruh dan berkesinambungan, sistematis, beracuan kriteria, serta accountable. Kunci keberhasilan terletak pada Tahap Perencanaan Pembelajaran Berbasis TIK dimana guru melibatkan pihak terkait dengan pembelajaran berbasis TIK dalam pembuatan RPP yang terintegrasi dengan TIK. Model ini juga dapat dikembangkan untuk melakukan supervisi pembelajaran dengan berbasis TIK.
Implementasi model manajemen pembelajaran berbasis TIK ini perlu memperhatikan beberapa hal, yakni: (1) Bagi pihak sekolah, dalam rangka mewujudkan PAIKEM serta visi sekolah, model manajemen pembelajaran berbasis TIK ini dapat dijadikan sebagai acuan untuk meningkatkan manajemen pembelajaran berbasis TIK pelaksanaannya belum efektif. Perlu ada kesiapan SDM, insfrastruktur dan peserta didik; (2) Bagi Guru perlu kerjasama dan komunikasi yang baik dengan pihak-pihak intern dan ekstern yang terkait langsung dengan pembelajaran; (3) Bagi kepala sekolah perlu meningkatkan supervisi pembelajaran agar manajemen pembelajaran terlaksana secara efektif dan efisien serta mengadakan pelatihan TIK secara berkala bagi guru-guru; (4) Koordinator IT perlu membentuk tim IT terdiri dari laboran dan programer yang membantu guru mempersiapkan konten digital yang sesuai dengan RPP yang terintegrasi dengan TIK; (5) Sekolah perlu memikirkan strategi untuk menggalang dana bagi peningkatan infrastruktur TIK dan pemeliharaannya; (6) Bagi penelitian selanjutnya, model manajemen pembelajaran ini dapat diteliti lebih lanjut apakah model ini dapat diterapkan pada lembaga pendidikan yang lain atau untuk dikembangkan bagi kegiatan supervisi pembelajaran.

\section{UCAPAN TERIMAKASIH}

Terimakasih yang sebesar-besarnya diucapkan kepada Prof. Dr. Slameto, M.Pd. yang telah memberikan bimbingan dalam penulisan artikel ini.

\section{DAFTAR PUSTAKA}

Adu, E.O. dan Olatundun, S. A. 2013. The Use And Management Of ICT In Schools: Strategies For School Leaders. European Journal of Computer Science and Information Technology

\section{Saran}


Pengembangan Model Manajemen Pembelajaran Berbasis TIK di Sekolah Dasar | Edna Maria \& Eko Sediyono

(EJCSIT)Vol.1, No.2, pp.10-16, September.

Anderson, Jonathan. 2010. ICT Transforming

Education. Bangkok: UNESCO.

Sumber:

http://www.unescobkk.org/education/n ews/article/ict-transforming-educationa-regional-guide-1/

Bafadal, Ibrahim. 2009. Manajemen Peningkatan Mutu Sekolah Dasar. Jakarta: Bumi Aksara.

Danurwati, Suprih dan Slameto. 2015. Penerapan Supervisi Kunjungan Kelas untuk Meningkatkan Kinerja Guru Sekolah Dasar Negeri. Jurnal Kelola Manajemen Pendidikan Vol.2 No.1 Januari-Juni 2015.

Gorton, Richard A. 1976. School Administration. New York: Wm. C. Brown Company Publishers.

Haryati, Sri. 2012. Research and Development $(R \& D)$ Sebagai Salah Satu Model Penelitian dalam Pendidikan. Jurnal UTM Volume 37 No.1 15 September 2012. Sumber: http://jurnal.utm.ac.id/index.php/MID/a rticle/viewFile/13/11 diakses tanggal 3 November 2015.

Kusmana, Ade. 2011. E-learning dalam Pembelajaran. Lentera Pendidikan Volume 14 No. 1 Juni.

Kyakulumbye, Stephen and Katono, Isaac Wasswa. 2013. The Management Practises of ICT Integration in the Curriculum of Primary Schools in Uganda. Proceedings of the International Conference on $e$ Learning, Academic Conferences \& Publishing International Ltd.

Sa'ud, Udin Syaefudin and Sumantri, Mulyani (Tim Pengembang Ilmu Pendidikan
FIP-UPI). 2007. Ilmu dan Aplikasi Pendidikan. Bandung: PT.IMTIMA, Grasindo.

Sugiyono. 2012. MetodePenelitianPendidikanPendekatanKuantitatif, Kualitatif, dan $R \& D$. Bandung: Alfabeta.

Syafaruddin dan Nasution, Irwan. 2005. Manajemen Pembelajaran. Jakarta: Quantum Teaching.

Tearle, Penni. 2004. A Theoretical and Instrumental Framework for Implementing Change in ICT in Education. Cambridge Journal of Education Vol. 34, No. 3, November.

Triwiyanto, Teguh. 2015. Manajemen Kurikulum dan Pembelajaran. Jakarta: BumiAksara.

Usman, Husaini. 2006. Manajemen Teori, Praktik, dan Riset Pendidikan. Jakarta: Bumi Aksara.

Vanderlinde, Ruben, Sara Dexter dan Johan van Braak, 2012. School-based ICT policy plans in primary education:Elements, typologies and underlying processes. British Journal of Educational TechnologyVol 43 No 3.

Wang, Qiyun., \& Woo, H. L. 2007. Systematic Planning for ICT Integration in Topic Learning. Educational Technology \& Society, 10 (1), 148-156.

Wang, Qiyun. 2008. A Generic Model for Guiding the Integration of ICT into Teaching and Learning. Innovations in Education and Teaching International Vol. 45, No. 4, November 2008, 411419. 